\title{
Response of Clementine Mandarin to Water-Saving Strategies under Water Scarcity Conditions
}

\author{
Mohamed El-Otmani ${ }^{1, *}$, Anouar Chouaibi ${ }^{1}$, Charif Azrof ${ }^{1}$, Lhoussaine Bouchaou ${ }^{2,3}$ (i) \\ and Redouane Choukr-Allah ${ }^{1}$ \\ 1 Departement of Horticulture, Institute of Agronomy and Veterinary Medicine Hassan II, Ait Melloul, \\ Agadir 80.150, Morocco; anouarchouaibi0@gmail.com (A.C.); charif.azrof@gmail.com (C.A.); \\ redouane53@yahoo.fr (R.C.-A.) \\ 2 Applied Geology and Geo-Environmental Laboratory, Faculty of Sciences, Ibn Zohr University, \\ Agadir 80.000, Morocco; 1.bouchaou@uiz.ac.ma \\ 3 International Water Research Institute (IWRI), Mohamed VI Polytechnic University, Agadir 80.000, Morocco \\ * Correspondence: elotmani.mohamed@gmail.com; Tel.: +212-661386216
}

Received: 21 July 2020; Accepted: 20 August 2020; Published: 30 August 2020

check for updates

\begin{abstract}
Water scarcity is the most constraining factor for crop production, especially in arid and semi-arid areas of Mediterranean countries such as Morocco. Within these conditions, different water-saving strategies using deficit irrigation (DI) were tested on two six-years old clementine varieties ('Sidi Aissa' and 'Orogrande'). These DI strategies were applied during the second part of fruit growth and during fruit maturation and included: the control treatment $(\mathrm{Cntl})$, in which the trees received $100 \%$ of crop evapotranspiration $(E T c)$ for the entire irrigation season; regulated deficit irrigation (RDI), with an application of $75 \%$ of ETc (RDI-1); partial rootzone drying (PRD), with an alternating irrigation between the two root system halves for 3-4 (PRD-3/4) and 7 (PRD-7) days, with an application of 50\% crop water requirements; and RDI-2, with an application of $50 \%$ of crop water needs during fruit maturation. The results indicate that the trees preferably absorb the water from the upper 0-30 cm-depth soil profile and that fruit drop was increased by PRD for 'Sidi Aissa', whereas RDI-1 had no effect on this parameter. The DI strategies had no effect on fruit drop for 'Orogrande'. The PRD reduced fruit size, yield and fruit juice content, with the effect being more pronounced on 'Sidi Aissa'. The RDI-1 had no effect on fruit yield for 'Orogrande' but reduced it for 'Sidi Aissa'. RDI-2 had no effect on yield, fruit size or fruit juice content. The DIs tested increased water use efficiency and enhanced fruit maturation as a result of increased juice sugar content and reduced acidity. The PRD tends to increase salt accumulation in the rootzone. Overall, 'Orogrande' was less sensitive to water stress and was more water-use efficient, and, under the semi-arid conditions of the experimental zone, PRD should not be used on clementine.
\end{abstract}

Keywords: citrus; deficit irrigation; yield; fruit size; fruit quality; water use efficiency

\section{Introduction}

Morocco, located in the southern rim of the Mediterranean basin, has a semi-arid climate and observes scare and overexploited water resources [1,2]. The demand for water resources increases in time and space due to urbanization, tourism, industry and agriculture [3]. Agriculture alone consumes about $80 \%$ of water resources used in the country, and more than $90 \%$ in the Souss-Massa plain, located in the central southwestern part of the country, the main region for intensive vegetable and fruit production in the country for domestic and export markets [4,5]. The availability of surface and groundwater (GW) is very limited, due to low precipitation (less than $200 \mathrm{~mm}$ of rain/year) and to the low water table recharge [6-8]. This decrease in water yield recharge under climate change combined 
with overexploitation led to a serious quality degradation and depletion of GW, which constitutes a strategic water supply for the region [9-11].

Citrus orchards cover about 40,000 ha (i.e., $82 \%$ of the land used for irrigated crops) in the Souss-Massa region and represent $31 \%$ of the national citrus acreage with very diverse variety profile in which the clementines occupy $50 \%$ of the plantings with a dozen of varieties $[12,13]$. Drip irrigation is the main water supply technique adopted because of its greater water use efficiency (WUE), increased fertilizer efficiency and contribution to preservation of the environment [14-16]. As for other fruit trees, citrus water consumption varies according to climatic factors, crop factors, agronomic management factors and soil factors [17-20]. At full canopy development, mature citrus orchards use between 700 to $1300 \mathrm{~mm}_{\text {year }}^{-1}$, with an average of $1000 \mathrm{~mm}_{\text {year }}^{-1}$ [20,21]. In this region, citrus flowering occurs in March, fruit-set in April and fruit enlargement takes place in the summer months coinciding with high crop evapotranspiration [20-22]. A fruit drop period known as the physiological drop or the "June drop" occurs in May, during which, the tree load is naturally regulated as a result of tree nutrition potential. Fruit drop can be enhanced by adverse conditions such as heat, drought or suboptimal irrigation and nutrition, whereas fruit enlargement can be reduced by these factors [20-24].

Water scarcity in the region forced researchers and growers alike to seek innovative irrigation strategies for additional water-saving and higher WUE in crops. Deficit irrigation (DI) has been proposed as an issue. It is a practice where water supply is below crop water requirements but with little or no negative effect on crop yield and quality [25-27]. The DI is also reported to have economic advantages, such as water saving or induction of early fruit maturation [28-30].

The DI strategies, including sustained deficit irrigation (SDI), regulated deficit irrigation (RDI) and partial rootzone drying (PRD), have been tested in different crops [27-33]. The SDI strategy consists of an irrigation practice to uniformly reduce water supply to crops below their water requirement throughout the growing season $[27,29,30]$. The RDI strategy consists of deliberately applying, at specific phonological stages, less water than the crop needs with little or no significant effect on yield and quality of the crop [31]. The PRD strategy consists of irrigating only half of the rootzone in each irrigation event, while the other half is left to dry to a certain level of soil water content before rewetting by shifting irrigation to the dry side [33].

In citrus, application of RDI at different tree phonological stages using water restrictions of 25 to $50 \%$ of crop requirements had a significant effect on tree response, with varied effects on yield, fruit size and fruit quality $[25,26,29,30]$. In particular, water saving of 12 to $18 \%$ during the period of fruit enlargement, compared to control (Cntl), had no effect on yield or fruit size [25]. Severe water stress can significantly impair tree performance [34,35]. The WUE increased for RDI treated trees compared to Cntl trees [34-37].

The PRD strategy was tested on various crops and is reported to be a viable irrigation option to increase water use efficiency and productivity, enhance fruit quality and allow water saving [33,38-41]. On citrus, PRD experiments increased root growth in the dry root-half with no significant effect on plant vegetative growth [42-44]. The application of PRD on citrus from flowering to fruit harvest with monthly alternating irrigation cycles between the two root halves resulted in $40 \%$ reduction in water use and increased WUE [44]. The PRD had no effect on fruit drop or fruit yield although a certain degree of reduced fruit size was observed. In addition, fruit of PRD trees had lower juice content and higher sugar and acid content but lower fruit maturity index. On orange trees, PRD supplying 50\% of crop with alternating between sides at weekly intervals allowed $41 \%$ water saving and reduced vegetative growth with no significant effect on fruit yield or juice content although some fruit size reduction was observed $[45,46]$. The WUE, sugar and acid content in juice were increased and the extent of increase was proportional to water stress imposed upon the trees.

Detailed information on the seasonal pattern of soil water content and its daily changes for citrus is scarce. Compared to citrus trees receiving full irrigation, PRD trees with weekly alternation of irrigation between the two rootzone halves had soil water content reaching the permanent wilting 
point during the week of no-irrigation cycle [46]. On grapevines, longer PRD drying cycles (14-16 days) dried more of the soil profile, and magnified the differences between the soil volumetric water content in the dry and that in the wet-side of the rootzone, with no negative effect on root function and water uptake [47].

Citrus tree growth and fruit yield are reported to decrease with increasing soil salt content above the threshold limit of $1.4 \mathrm{dS} \mathrm{m}^{-1}$ (expressed as saturated soil-paste extract) [48] to $1.8 \mathrm{dS} \mathrm{m}^{-1}$ [49], depending mainly on the variety, the rootstock and the salt chemical composition. Techniques and strategies of water supply to trees have a significant effect on accumulation/leaching of salts in the soil and accumulation of salts in the soil was reported to have a negative impact on tree performance and fruit development $[50,51]$. The use of RDI on citrus produces a temporary concentration of salts in the rootzone [29]. DI applied to fruit trees using micro-irrigation and moderately saline water was reported to increase soil salinization [52]. Since all of the citrus is under drip irrigation and that the degradation in water quality in the Souss-Massa region may result in salt build up in the soil, particular attention is given to this aspect.

In the Souss-Massa region, clementine mandarin fruits mature in September for the early varieties, in October for the mid-early, in November for the mid-season and in December for the late-maturing ones $[53,54]$. However, to avoid the peak production of November and obtain high market prices early in the season, growers withhold irrigation during fruit maturation to boost sugar accumulation and induce early fruit maturation $[53,55,56]$. However, studies on the DI strategy to be used in the region, the adequate duration and degree of stress to be applied without hampering tree performance, and the resulting effect on fruit yield and quality, as well as on soil salinity and water saving are scarce.

This research has the general goal of testing innovative DI strategies to promote water saving in citriculture particularly in the semi-arid Souss-Massa region. The specific objectives of the trial are to: (i) study the effect of RDI and PRD irrigation strategies, applied to trees of two semi-early clementine varieties during the second half of fruit growth stage and during fruit maturation, on the seasonal pattern of volumetric soil water content; (ii) investigate the effect of these DI strategies on fruit yield, fruit size and quality, water savings, tree WUE and soil salinization; (iii) detect any varietal differences and conclude on best DI strategy to be recommended for the clementine growers in the region.

\section{Materials and Methods}

\subsection{Experimental Site Characteristics and Crop Management}

The trial was performed during 2017 in a commercial orchard located in the Souss valley of Morocco (Latitude: $31.80^{\circ} \mathrm{N}$; Longitude: $8.78^{\circ} \mathrm{W}$ ) with a semi-arid climate. Two mid-early clementine varieties (Citrus reticulata Blanco) were used: 'Sidi Aissa' grafted on 'Carrizo' citrange (Citrus sinensis L. (Osb.) X Poncirus trifoliata L. (Raf.)) and 'Orogrande' grafted on Citrus volkameriana. The trees were planted in 2011 on a sandy loam soil with a water content at field capacity (SWFC) of $28 \%$, a water content at the permanent wilting point (SWWP) of $14 \%$, a $\mathrm{pH}$ of 7.1 and an electric conductivity (EC; based on 1:5 soil to water ratio extract) of $0.18 \mathrm{dS} \mathrm{m}^{-1}$. Before planting, the soil was plowed and mixed over a depth of $60-80 \mathrm{~cm}$. The trees were planted at a spacing of $6 \mathrm{~m} \times 2 \mathrm{~m}$, on ridges made from the soil taken from the area between the rows to increase soil depth and have better water drainage in the orchard [57]. These ridges have approximately $25 \mathrm{~cm}$ in height and $3 \mathrm{~m}$ in width.

The trees were ferti-irrigated using two lines of drippers for each tree row, one in each side of the row placed 1.0 to $1.2 \mathrm{~m}$ away from the tree trunk. The drippers were $60 \mathrm{~cm}$ apart on the line (i.e., 6.6 drippers/tree) and have a flow rate of $4 \mathrm{~L} \mathrm{~h}^{-1}$ dripper ${ }^{-1}$ leading a system rainfall of $2.2 \mathrm{~mm} \mathrm{~h}^{-1}$. Irrigation water had a $\mathrm{pH}$ of 6.9 and an $\mathrm{EC}$ of $1.18 \mathrm{dS} \mathrm{m}^{-1}$. The experimental plot received cultural practices that are optimal for the region. Trees were pruned in January and fertilized with 110, 42, $110 \mathrm{~kg} \mathrm{ha}^{-1}$ year $^{-1}$ of $\mathrm{N}, \mathrm{P}_{2} \mathrm{O}_{5}, \mathrm{~K}_{2} \mathrm{O}$ respectively, split in weekly applications from March to early September. Water dosage was applied once a day in mid-morning. Control of weeds, diseases and pests was done according to local criteria and regulations. 


\subsection{Estimation of Crop Evapotranspiration, Description of the Irrigation Treatments and Experimental Design}

The experiment was laid out as a complete bloc design with 4 replications per treatment. The blocs (= replications) were made within rows with one bloc per row. Two guard trees were used between treatments within the rows. Since drip irrigation was used and that the rows were sufficiently far away from each other no guard rows were left between adjacent rows. Experimental units had 5 trees each. The treatments were assigned to the experimental units at random. Application of the irrigation strategies begun on 6 July 2017 and lasted during the whole fruit growth and maturation stages (up to 2 October 2017) according to the specifications described in Table 1. Irrigation regimes were based on growers' experience coupled with frequent observations of the general status of the tree leaves and of the soil water content using capacitance probes. After verifying the root depth of trees and lateral extent of the root system for both varieties, the net maximum water dose to be applied at one time was calculated giving a value of $3.2 \mathrm{~mm}$, i.e., an irrigation duration of $1 \mathrm{~h} 30 \mathrm{~min}$, using the irrigation system described above. This amount corresponds to the daily crop water requirements (also known as crop evapotranspiration (ETc)) during the summer period. The ETc was calculated using the following formula:

$$
\mathrm{ETc}=\mathrm{ETo} \times k_{c}
$$

where

ETo: the reference evapo-transpiration, estimated using the FAO Pennman-Monteith equation based on weather data [17] obtained from the closest meteorological station (Latitude: $30.52^{\circ} \mathrm{N}$; Longitude: $8.71^{\circ} \mathrm{W}$ ) and kindly made available to us by Phytoconsulting (www.Phytoconsulting.com), who runs and manages the regional weather-station network in the Souss-Massa region.

$k_{c}$ : the crop cultural coefficient [17]. For the varieties used in this trial, the trees were of similar size and vigor and thus, their crop coefficients were identical and varied with the season: 0.3 in December, January and February; 0.5 in September, October, November, March, April and May; and 0.6 in June, July and August. The $k_{c}$ value was adjusted to the local conditions with $50 \%$ of soil cover by the trees, dry conditions with clean soil and light winds based on previous research $[58,59]$ in the region and further development by Phytoconsulting. Phytoconsulting has developed an irrigation management software (named "Yobeen") for citrus in the region that takes into account the season of the year and its climatic parameters, the variety, the rootstock, tree density and soil cover and crop load. It personalizes irrigation scheduling, and, via SMS messages, it provides the growers with daily information on crop water requirements.

Table 1. Irrigation strategies tested.

\begin{tabular}{cc}
\hline Irrigation Strategy & Specifications \\
\hline Cntl & Grower's strategy: supply of 100\% ETc \\
RDI-1 & supply of 75\% ETc from 6 July to 2 October 2017 \\
PRD-3/4 & irrigation with alternating between the two root system halves at 3- to 4-day \\
& intervals from 6 July to 2 October 2017 (supply of 50\% ETc) \\
PRD-7 & irrigation with alternating between the two root system halves at 7-day interval \\
& from 6 July to 2 October 2017 (supply of 50\% ETc) \\
RDI-2 & irrigation with supply of 100\% ETc during fruit growth stage (6 July to 10 September \\
& 2017) and 50\% ETc during fruit maturation (from 11 September to 2 October 2017) \\
\hline
\end{tabular}

\subsection{Data Collection and Reporting}

Data on the following parameters was collected and/or monitored:

Weather data were obtained from the closest field weather station as indicated above measuring air temperature, air relative humidity, rainfall, wind speed, air vapor pressure deficit (VPD) and reference evapotranspiration, and analyzed to characterize the climate for the experimental season.

AquaCheck capacitance probes (from AquaCheck, Durbanville, South Africa), with sensors at $10,20,30,40,50$ and $60 \mathrm{~cm}$ depths, were used to record soil moisture in the upper soil $60 \mathrm{~cm}$ depth 
for 'Orogrande' clementine. Before the start of the study, tree root distribution was checked for both varieties, and was found to be mostly concentrated in the first $40 \mathrm{~cm}$ soil-depth. Since no probes were available for use on 'Sidi Aissa', that the trees of the two varieties had identical canopy volume and vigor, it was assumed that the two varieties have identical water requirements and, therefore, the water supply was similar for the two varieties. In addition, soil moisture checks during the experimental period indicated that there was no water percolation beyond the root system depth for both varieties. Calibration curves correlating capacitance probe readings and volumetric soil water content were obtained using soil samples taken at different soil depths in the $0-60 \mathrm{~cm}$ soil profile, and used to monitor soil water status. The Cntl, RDI-1 and PRD-3/4 had one capacitance probe each placed perpendicular to the row line, in the west side of the tree, at $10-15 \mathrm{~cm}$ from the dripper. PRD-7 had one probe placed on the east side and one placed on the west side of the same tree. RDI-2 had no probe.

Fruit drop counts and fruit size measurements were recorded. Four trees per treatment (one tree per bloc) were marked at the start of the experiment. On these trees, four fruiting shoots per tree (one shoot per tree quadrant) were tagged and their fruit count was recorded. Fruit drop was then monitored from 6 July to 10 September 2017, the date where no further drop occurred. For each replication, an average fruit drop percentage was calculated over the four shoots of the tree representing the replication. Data are reported as percentage drop relative to the number of fruits at the start of the experiment (6 July 2017). In addition to that, one fruit per shoot was tagged, and its diameter was recorded at two-week intervals. A mean value representing the replication was obtained using the four data values recorded for each of the trees representing the replication. The calculated average was then used in the statistical analyses.

On 2 October 2017 (the start of the commercial harvest), fruit number per tree was counted and the average fruit weight was obtained using samples of twenty fruits per replication, picked at random. Estimated fruit yield per tree was calculated using the five trees in each replication. The obtained value was extrapolated to the hectare unit and used for statistical analysis ( $\mathrm{n}=4$ replications). From each block, a sample of 10 fruits was used to assess effect of irrigation regimes on fruit quality. Fruit juice content was obtained and its total soluble solids content (TSS; in \%) was obtained using a laboratory refractometer. Juice titratable acidity (A; in \%) was obtained by juice titration using $0.1 \mathrm{~N} \mathrm{NaOH}$ solution. Maturity index (MI) was then calculated as: MI = TSS/A.

Water quantities supplied to the trees during the experimental period and during the whole crop production cycle (from the beginning of November 2016 (estimated to be the beginning of onset of flower initiation for clementine) to the end of October 2017) were determined for each irrigation strategy and water use efficiency (WUE) was estimated as the number of kilograms of fruit produced per unit of water used $\left(\mathrm{m}^{3}\right)$, as reported by others [34-37]. For each treatment, soil salinity was assessed at the end of the experiment using composite soil samples taken from the four treatment replications. The samples were taken at each soil depth within the $0-60 \mathrm{~cm}$ soil profile, in the zone of $10-15 \mathrm{~cm}$ away from the drip head and perpendicular to the row. Soil electrical conductivity was obtained in the laboratory using the 1:5 soil-to-water ratio extract standard method [60].

\subsection{Statistical Analyses}

Data were subjected to a normality test using the Shapiro-Wilk test on residuals followed by an analysis of variance using Minitab Statistical Software (Minitab Ltd., Coventry, UK). Mean separation was performed using Tukey's test at 5\% [61]. Regression analysis was made for the relationship between fruit yield and fruit count and individual fruit weight on the one hand, and between water supply and individual fruit weight, fruit yield and WUE on the other hand.

\section{Results and Discussion}

\subsection{Characterization of the Climate during the Clementine Production Cycle}

Analysis of the climate for the crop cycle shows that: 
- Annual mean air temperature was $21.1^{\circ} \mathrm{C}$, with average minimum temperatures and average maximum temperatures of $13.5^{\circ} \mathrm{C}$ and $28.6^{\circ} \mathrm{C}$, respectively. The climate was relatively mild in the winter and hot in the spring with minimum readings above $5^{\circ} \mathrm{C}$ and maximum values ranged from 20 to $35^{\circ} \mathrm{C}$, coinciding with tree dormancy, bud-break, flowering and fruit set, and very hot in the summer with values reaching 40 to $46^{\circ} \mathrm{C}$ during the months of June to August.

- Daily average relative air humidity was mostly in the $40-70 \%$ range (with an annual mean of $60 \%$ for the maximum daily readings) and minimum daily values were frequently below $35 \%$ (with an annual mean of $33 \%$ ).

- Total rainfall during the crop cycle was $325 \mathrm{~mm}$ of which 130 fell in November-December 2016, coinciding with winter rest of the trees, $135 \mathrm{~mm}$ fell in the month of February 2017, coinciding with bud-break and $60 \mathrm{~mm}$ fell in August 2017, coinciding with fruit enlargement.

- Daily VPD values were in the range of 0.5-1.5 kPa during mild temperature periods of winter and early spring and increased to maximum values in the range of 3-5 $\mathrm{kPa}$ from mid-June to mid-August.

- In addition, ETo was in the 1-4 $\mathrm{mm} / \mathrm{d}$ range during the winter-fall season and 4-9 $\mathrm{mm} / \mathrm{d}$ in the spring-summer period, with maximum values recorded in the months of March coinciding with flowering, and May through August, coinciding with the physiological fruit drop and fruit enlargement (Figure 1).

Therefore, it can be concluded that during this clementine production cycle (from 1 November 2016 (i.e., the beginning of the period of flower initiation to the end of October 2017 (i.e., fruit harvest period)), dry conditions prevailed. In addition, most of the rain fell during the period of November-February, which coincides with low tree water demand, as the citrus varieties included in this trial are still in a semi-dormant stage, with average air temperatures below $18^{\circ} \mathrm{C}$. Spring and summer months were dry and hot with maximum evapotranspiration. It was reported that citrus trees are sensitive to temperatures greater than $36{ }^{\circ} \mathrm{C}$ [62], to air humidity below 30\% [63] and to VPD greater than $2.4 \mathrm{kPa}$ [64], particularly during flowering, fruit set and fruit growth. These conditions are inductive of flower and fruit drop, and of the inhibition of fruit growth, which can be aggravated by the suboptimal supply of irrigation water and nutrition [23].

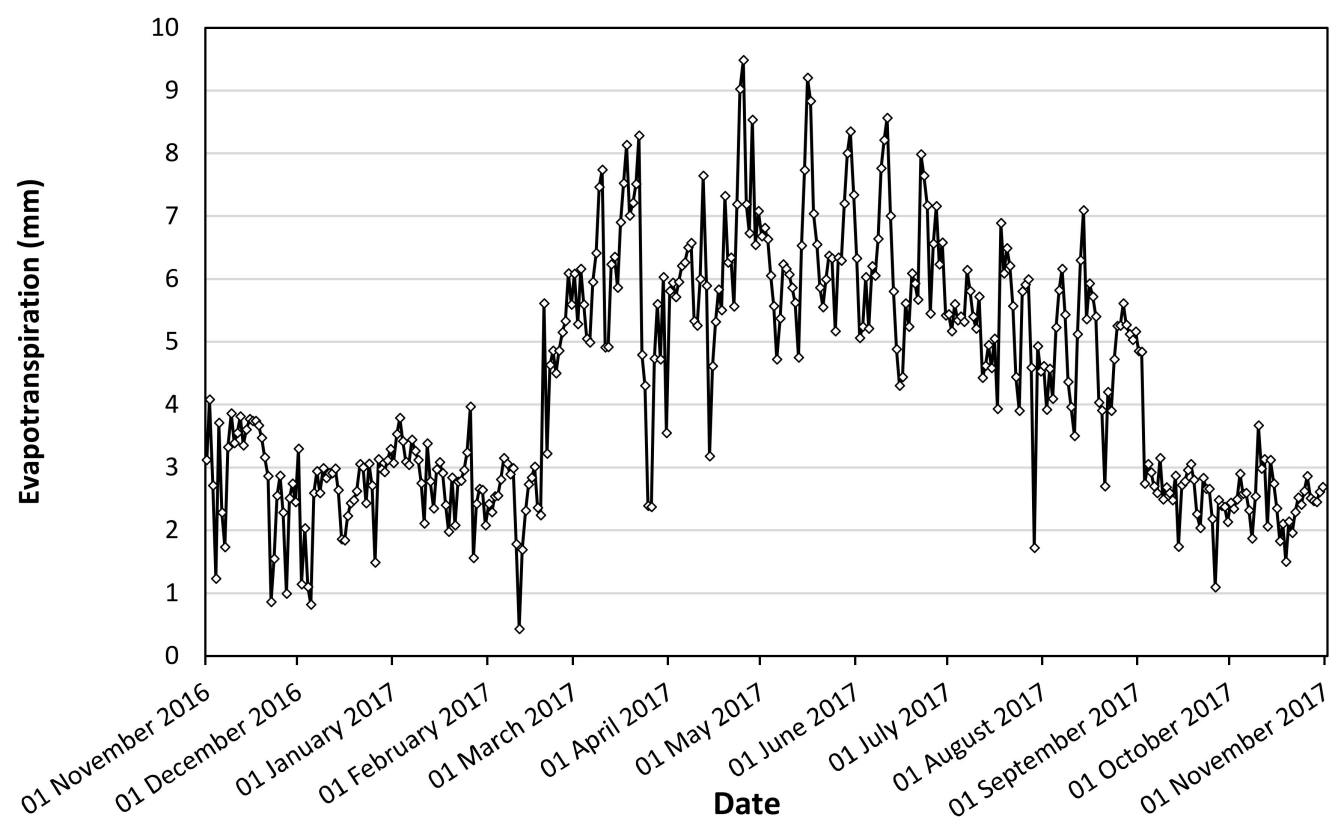

Figure 1. Pattern of daily reference crop evapotranspiration during the clementine crop cycle. 


\subsection{Effect of Irrigation Strategy on Seasonal Pattern of Soil Volumetric Water Content}

After capacitance probe calibration and verification, a highly significant positive correlation was obtained between volumetric soil water content and capacitance probe readings, regardless of the treatment. In fact, the correlation coefficients ' $r$ ' between probe readings and soil volumetric water content are 0.90, 0.97, 0.97, 0.95 and 0.95, respectively for ', RDI-1, PRD-3/4, PRD-7 east and PRD-7 west. Figures $2-5$ show the pattern of the soil volumetric water content and its variation with the treatment and the soil depth for representative periods in August 2017. In general, after an irrigation event, recorded values are within the range of SWFC $(=28 \%)$ and SWWP $(=14 \%)$ with peaks observed for the $0-30 \mathrm{~cm}$ soil depths, shortly after water application, regardless of the treatment. The pattern of this content changes with soil depth depending on treatment. No water percolation was noticed during the experimental period for both varieties.

For Cntl trees, soil water content is highest $(>20 \%)$ in the $0-20 \mathrm{~cm}$ soil layer and decreases in the deeper profiles to reach $17 \%$ in the $40-60 \mathrm{~cm}$ soil profile (Figure 2). Soil desiccation generally occurs in the upper $0-10 \mathrm{~cm}$ soil layer, followed by the $10-20 \mathrm{~cm}$ profile. Soil profiles deeper than $30 \mathrm{~cm}$ have the least water content (17-20\%) with values quasi unchanged. Soil water content in the $20-30 \mathrm{~cm}$ layer is intermediate.

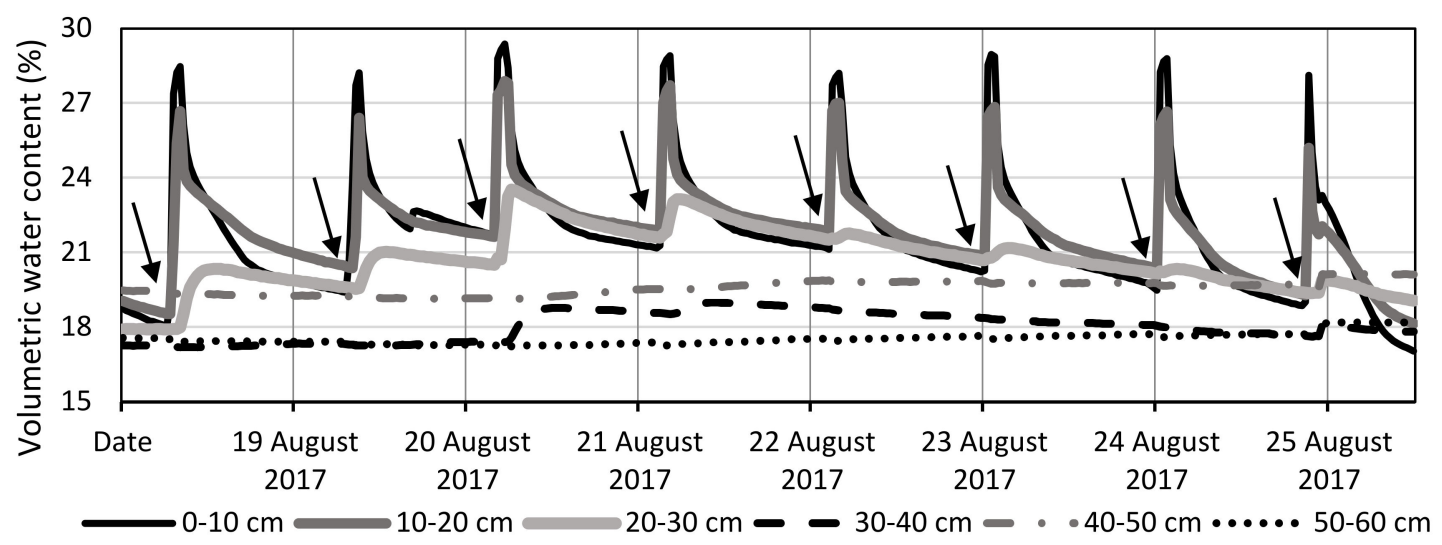

Figure 2. Pattern of soil volumetric water content during the period of 18 to 25 August for 'Orogrande' Cntl treatment according to soil depth. Arrows indicate irrigation application.

A detailed analysis of the changes taking place in the upper 40-cm soil profile (i.e., the rootzone with maximum active roots) for the Cntl treatment shows an increase in soil water content to reach a peak within 2 to $3 \mathrm{~h}$ after an irrigation event, after which the soil water content decreases as a result of crop evapotranspiration and the rate of the decrease is a function of evapotranspiration rate (Figure 3). During three consecutive high ETo days, soil water content within the upper 40-cm soil profile increases to a maximum of $75-80 \mathrm{~mm} / 40 \mathrm{~cm}$ after an irrigation and decreases rapidly to reach a minimum of $62 \mathrm{~mm} / 40 \mathrm{~cm}, 11$ to $12 \mathrm{~h}$ later (Figure 3A). During days with mild maximum temperatures and reduced ETo, soil water content increases to $85 \mathrm{~mm} / 40 \mathrm{~cm}$ after an irrigation event and decreases at a slower rate to reach values of $68-70 \mathrm{~mm} / 40 \mathrm{~cm}, 22-24 \mathrm{~h}$ later (Figure 3B). This shows clearly that trees respond to climatic demand with a more rapid water uptake by the roots, resulting in more rapid soil water depletion under conditions of high evapotranspiration, compared to days with low evapotranspiration.

For RDI- 1 trees, soil water content is also high in the $0-20 \mathrm{~cm}$ soil profile following an irrigation event, but with values lower than those recorded for Cntl trees (Figure 4A), concurring with the fact that RDI-1 trees receive 30\% less water compared to Cntl trees. In addition, soil water content decreases with soil depth with the 50-60 cm profile, recording the lowest values similar to those recorded for Cntl treatment. 


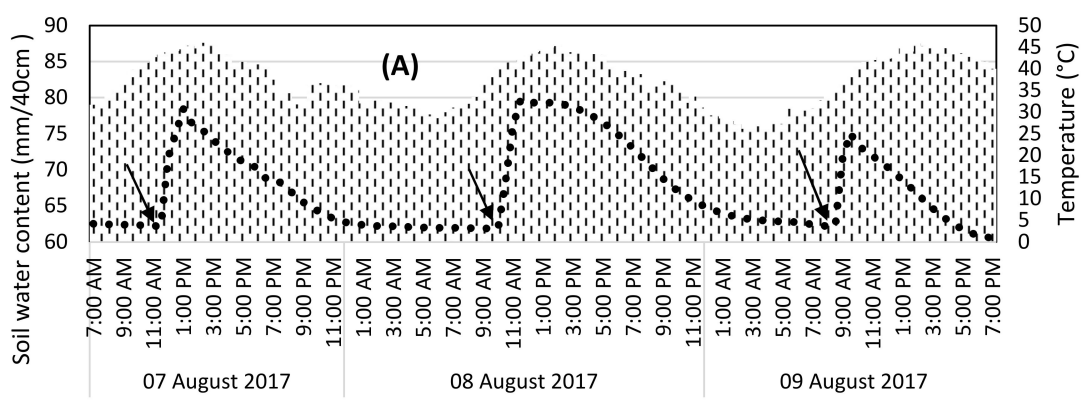

:1:1:1:1 Temperature $\left({ }^{\circ} \mathrm{C}\right) \quad$ •... Soil water content

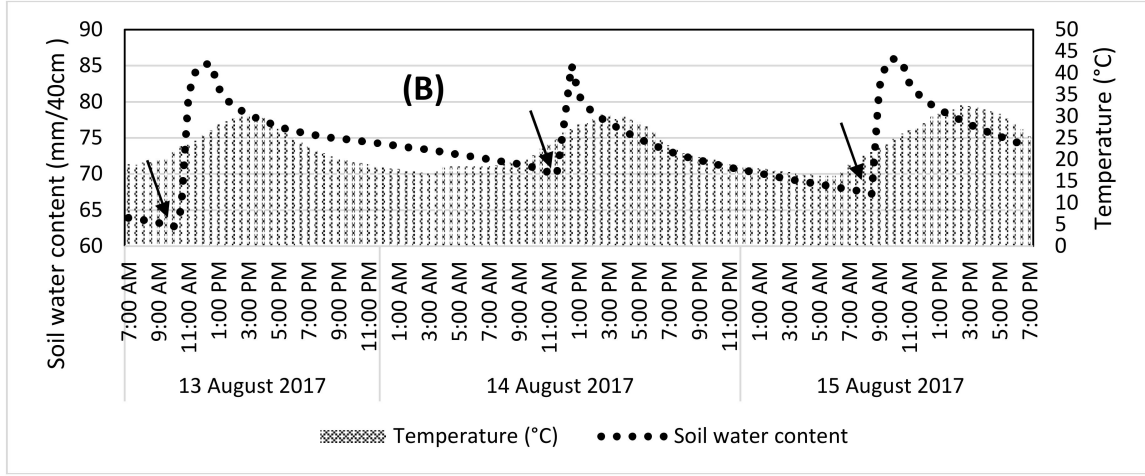

Figure 3. 'Orogrande' clementine soil volumetric water content in the upper 40-cm soil profile for three consecutive high-temperature days (7-9 August); (A) and three consecutive mild-temperature days (13-15 August); (B) for Cntl trees receiving full irrigation. Arrows indicate the time of water supply. Capacitance probe measurements were recorded every $15 \mathrm{~min}$.

Analysis of an irrigation cycle for the PRD strategies shows a different effect of the irrigation supply on the soil volumetric water content, particularly for the no-irrigation period shows data for two irrigation/no-irrigation cycles for PRD-3/4 shows that volumetric water content in the $0-30 \mathrm{~cm}$ soil profile is at least equal to $20 \%$ immediately after an irrigation and for the 3- to 4-day irrigation period, with values close to Cntl soil water content (Figure 4B). During the no-irrigation period, however, water content at these depths decreases significantly within two days of no-irrigation to values in the vicinity of the SWWP (with readings of $13 \%$ for the $0-10 \mathrm{~cm}$ layer and $14 \%$ for the $10-20$ and $20-30 \mathrm{~cm}$ depths) and remained quasi constant until the next irrigation event. For the $30-60 \mathrm{~cm}$ profile, soil water content is in the $15-18 \%$ range, and remained quasi constant during the experimental period. Figure 5 shows the pattern of soil water content during two consecutive weeks (i.e., one irrigation/no-irrigation cycle) of trial for PRD-7, with data for the capacitance probe placed in the east side (Figure 5) and that placed on the west side (Figure 5) of the same tree. During the irrigation week and immediately after an irrigation event, soil volumetric water content increases significantly in the $0-20 \mathrm{~cm}$ soil profile to reach $22-28 \%$ after each irrigation event, and decreases afterward to values of $18-19 \%$ (Figure 5). During the week of no-irrigation, soil desiccation is greater for the 0-10 cm layer with water content reaching $12 \%$ followed by the $10-20$ and the $20-30 \mathrm{~cm}$ soil-depth profiles, which all reach readings below the SWWP within three days of no-irrigation. In the $30-60 \mathrm{~cm}$ soil profile, the water content is in the range of $14-17 \%$, with values quasi constant during the whole experimental period.

These results indicate that under PRD, water is taken up by the trees in the upper 0-30 cm soil-depths quasi exclusively, whether it is for PRD-7 or PRD-3/4. The fact that during the period of no-irrigation volumetric soil water content in these soil profiles is lower than SWWP indicates that the trees have preference to extract water in these profiles where the roots are concentrated, and that the trees receive all of their water needs from the irrigated side. Consoli et al. [46] reported that for orange trees, alternating irrigation between tree sides at weekly basis resulted in a noticeable drying in the portion of the soil not irrigated of the PRD treatment (supplying $50 \%$ of ETc) and colonized by the roots 
(i.e., 0-30 cm profile), and reaching the permanent wilting point. Whether the trees develop more energy or produce more feeder roots to colonize these profiles remains to be explored. In grapes, increased root osmotic potential in PRD may also be involved [65]. In addition, PRD strategies were reported to stimulate greater fine root growth, increased soil volume exploration and water uptake [66,67]. Thus, the irrigated roots likely supply sufficient water to the shoots to maintain an adequate tree-water status that prevents tree-water deficit [42-46,68].

(A)

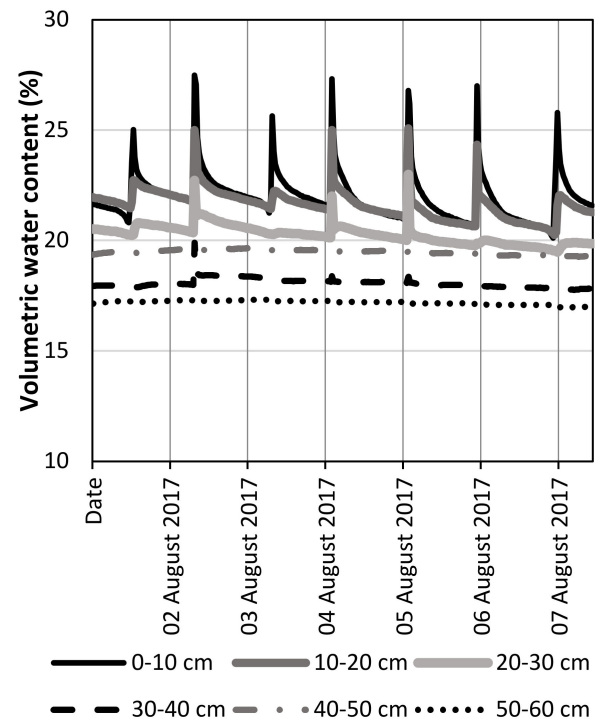

(B)

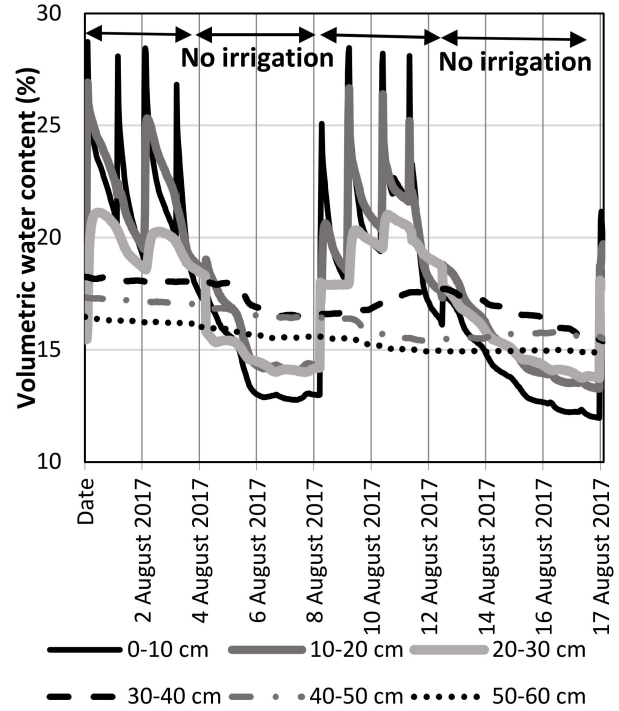

Figure 4. Pattern of soil volumetric water content for 'Orogrande' clementine during one week for regulated deficit irrigation (RDI)-1 (A); period of 1 August to 7 August) and two weeks (i.e., two irrigation cycles) for partial rootzone drying (PRD)-3/4 (B); period of 1 August to 17 August) treatments according to soil depth. Arrows indicate alternating irrigation and no-irrigation cycles. Measurements were recorded every 15 min using capacitance probes.

PRD-7 East side

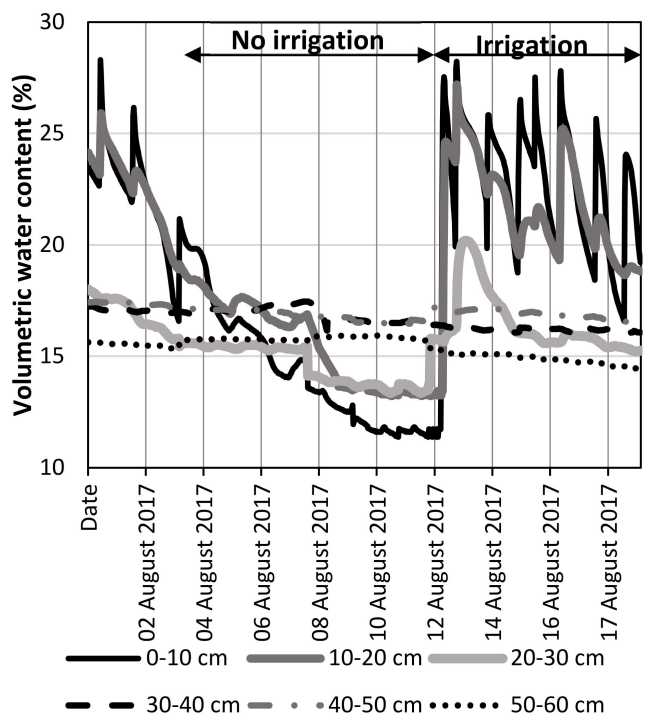

PRD-7 West side

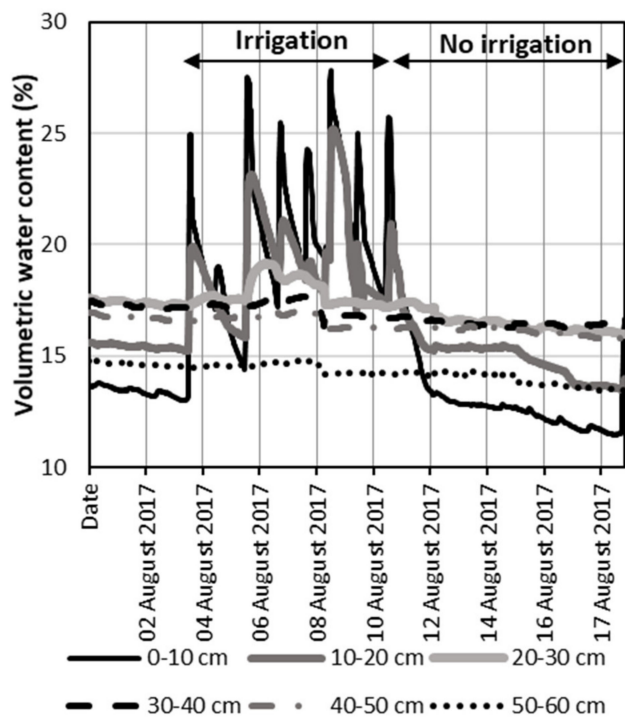

Figure 5. Pattern of soil volumetric water content for 'Orogrande' clementine during one representative PRD-7 irrigation/no-irrigation cycle in August 2017. Capacitance probes were placed in the east side and the west side of the same tree and measurements were recorded every $15 \mathrm{~min}$. Arrows indicate the alternation between periods of irrigation and periods of no-irrigation. 
Water deficit stress conditions resulting from the use of DI are reported to reduce crop evapotranspiration and, consequently, reduce photosynthetic rates and $\mathrm{CO}_{2}$ fixation [43,69]. As a result, tree vegetative development, fruit size and crop yield can be negatively affected [29,70-72].

\subsection{Effect of Irrigation Strategies on Fruit Drop, Fruit-Growth Pattern and Final Fruit Size}

It should be pointed out that RDI-2 trees received the same amount of water as Cntl trees during the period of fruit drop evaluation and, thus, for fruit drop, only data for Cntl trees were recorded and are presented. During the experimental period, none of the irrigation strategies had any effect on fruit drop for 'Orogrande'; however, PRD strategy increased this parameter for 'Sidi Aissa' whereas RDI-1did not (Table 2). In fact, fruit drop for 'Sidi Aissa' under PRD was 33-36\% higher compared to Cntl. This fruit drop difference was in the range of $6-14 \%$ for 'Orogrande'. This effect on the fruit drop was also reflected in fruit number per tree at harvest, which was significantly lower for 'Sidi Aissa' trees receiving either RDI-1 or PRD (with PRD-7 resulting in the lowest fruit number although statistically not different from RDI-1 or PRD-3/4; Table 2). Therefore, it appears that 'Sidi Aissa' is more sensitive to water deficit stress, and particularly to PRD, since the fruit drop rate was significantly higher. The application of PRD to navel orange trees from flowering to fruit harvest with monthly alternating irrigation cycles and obtained $40 \%$ water savings, with no effect on fruit drop [44]. Similarly, no detrimental effect was reported for use of PRD on blood orange trees with alternating irrigation between tree sides at one-week intervals [46].

Fruit growth curve for 'Orogrande' (Figure 6) as well as for 'Sidi Aissa' (data not shown) has a sigmoidal pattern similar to that reported by others [22]. Reducing the water supply to trees below their optimal requirements reduced the rate of fruit growth with a less pronounced effect on RDI-1 fruit (Figure 6). The PRD strategy, however, had the greatest negative effect on fruit growth, with impact of PRD-7 being equal to that of PRD-3/4. This trend was similar for both cultivars and, consequently, fruit size at harvest is affected, and the reduction rate is closely related to the degree of water deficit for both cultivars (Table 2). In fact, RDI-1 caused $10 \%$ and $6 \%$ reduction in fruit diameter respectively for 'Sidi Aissa' and 'Orogrande', while RDI-2 applied during fruit maturation generated only 1\% reduction. The PRD strategy, however, caused a 13-14\% reduction in fruit diameter for 'Sidi Aissa' and a $5-7 \%$ reduction for 'Orogrande'. This impact of irrigation strategies on fruit diameter is also reflected in individual fruit weight (Table 2). A linear regression analysis for both cultivars indicate a significant correlation between the amount of water applied and individual fruit diameter and that the amount of water applied explained $84 \%$ and $97 \%$ of the variability observed in the individual fruit weight, respectively, for 'Sidi Aissa' and 'Orogrande' (Table 3). Reduced fruit size as a result of water deficit is reported on clementine $[29,34,35]$. It should be noted that, although there is a significant correlation between individual fruit diameter and weight for clementine mandarins with a correlation coefficient ' $r$ ' $>0.96$ [73], the former is used for commercial purposes [74] and a gain or a loss of 2 to $3 \mathrm{~mm}$ per fruit is a gain or a loss in monetary benefits to the grower, since for clementine fruits, the larger fruit sizes procure greater prices in the market place [72].

Table 2. Effect of irrigation strategies on fruit drop (as \% of fruit fallen between the dates of 6 July and 10 September 2017), and on fruit count per tree and on individual fruit diameter and individual fruit weight for 'Sidi Aissa' and 'Orogrande' clementines at harvest date (2 October 2017)

\begin{tabular}{|c|c|c|c|c|c|c|c|c|}
\hline \multirow{2}{*}{$\begin{array}{c}\text { Irrigation } \\
\text { Strategy }\end{array}$} & \multicolumn{4}{|c|}{ 'Sidi Aissa' } & \multicolumn{4}{|c|}{ 'Orogrande' } \\
\hline & $\begin{array}{l}\text { Fruit Drop } \\
(\%)\end{array}$ & $\begin{array}{c}\text { Fruit Number } \\
\text { Per Tree }\end{array}$ & $\begin{array}{l}\text { Fruit Diameter } \\
\text { (mm) }\end{array}$ & $\begin{array}{l}\text { Fruit Weight } \\
\left.\text { (g fruit }^{-1}\right)\end{array}$ & $\begin{array}{c}\text { Fruit Drop } \\
(\%)\end{array}$ & $\begin{array}{l}\text { Fruit Number } \\
\text { Per Tree }\end{array}$ & $\begin{array}{l}\text { Fruit Diameter } \\
\text { (mm) }\end{array}$ & $\begin{array}{c}\text { Fruit Weight } \\
\text { (g Fruit }^{-1} \text { ) }\end{array}$ \\
\hline Cntl & $10.9 \mathrm{a}$ & $334 \mathrm{a}$ & $48.5 \mathrm{a}$ & $55.4 \mathrm{a}$ & $8.8 \mathrm{a}$ & $356 a$ & $57.0 \mathrm{a}$ & $66.4 \mathrm{a}$ \\
\hline RDI-1 & $11.9 \mathrm{a}$ & $318 \mathrm{~b}$ & $43.5 \mathrm{~b}$ & 53. $6 \mathrm{ab}$ & $9.8 \mathrm{a}$ & $335 \mathrm{a}$ & $53.5 \mathrm{~b}$ & $64.3 \mathrm{~b}$ \\
\hline PRD-3/4 & $14.5 \mathrm{~b}$ & $295 \mathrm{~b}$ & $42.0 \mathrm{c}$ & $52.6 \mathrm{~b}$ & $9.3 \mathrm{a}$ & 320 a & $52.0 \mathrm{c}$ & $61.4 \mathrm{c}$ \\
\hline PRD-7 & $14.8 \mathrm{~b}$ & $279 \mathrm{~b}$ & $41.8 \mathrm{c}$ & $51.4 \mathrm{~b}$ & $10.0 \mathrm{a}$ & 325 a & $51.7 \mathrm{c}$ & $60.7 \mathrm{c}$ \\
\hline RDI-2 & NA & 348 a & $47.8 \mathrm{a}$ & $55.7 \mathrm{a}$ & NA & 344 a & $56.7 \mathrm{a}$ & $65.4 \mathrm{ab}$ \\
\hline
\end{tabular}

Within columns, values followed by the same letters are not statistically different (Tukey's test at $5 \%$ level). 


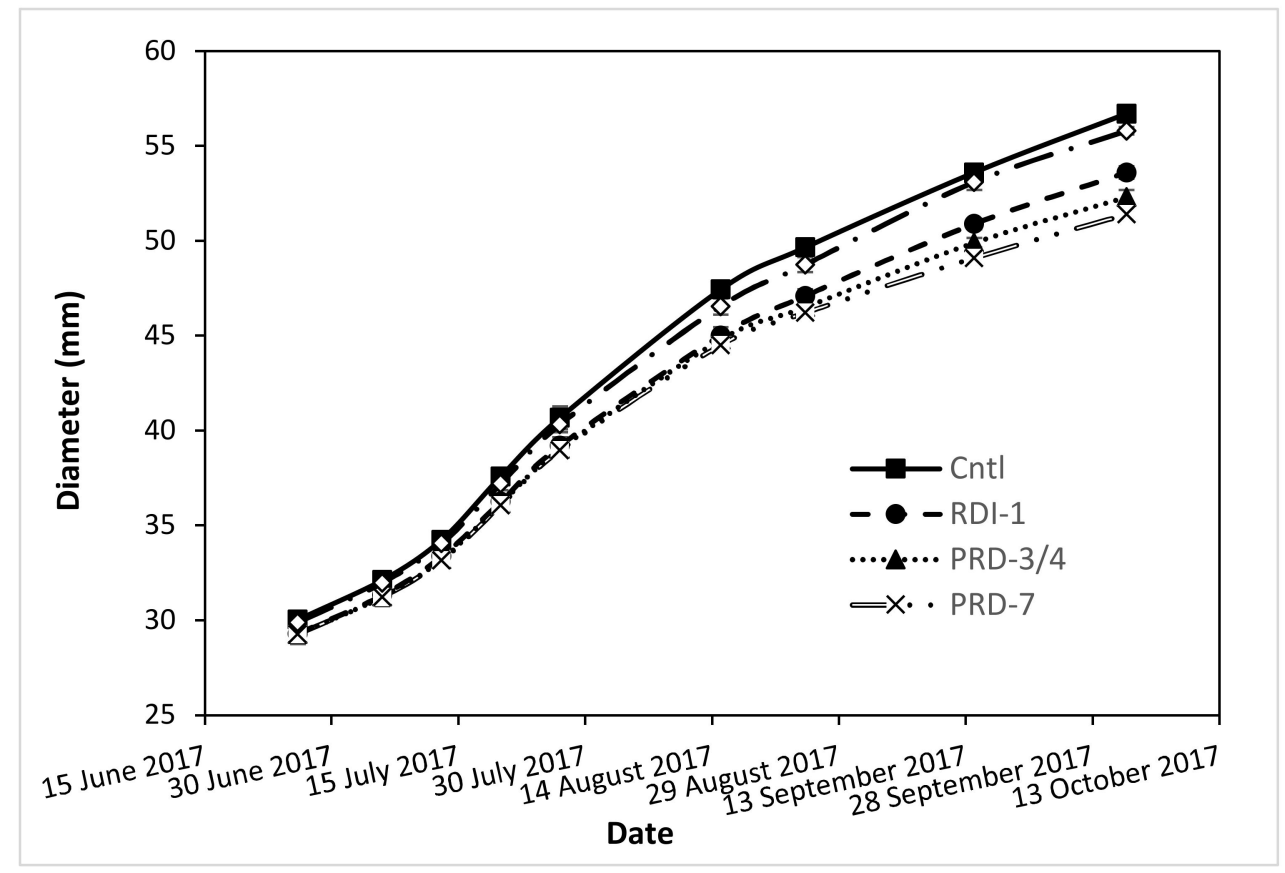

Figure 6. Effect of irrigation strategy on pattern of growth of fruit equatorial diameter for 'Orogrande' clementine.

Table 3. Linear regression analysis between amounts of water applied $\left(x ;\right.$ in $\left.1000 \mathrm{~m}^{3}\right)$ and individual-fruit weight ( $\mathrm{g}_{\text {fruit }}{ }^{-1}$ ) and yield (tons ha ${ }^{-1}$ ) for 'Sidi Aissa' and 'Orogrande' clementines.

\begin{tabular}{ccccc}
\hline Relationship & Cultivar & $\begin{array}{c}\text { Regression } \\
\text { Equation }\end{array}$ & $\begin{array}{c}\text { Regression } \\
\text { Coefficient } \boldsymbol{r}\end{array}$ & $\begin{array}{c}\text { Coefficient of } \\
\text { Determination } \boldsymbol{R}^{\mathbf{2}} \mathbf{( \% )}\end{array}$ \\
\hline $\begin{array}{c}\text { Between water supply (x) } \\
\text { and fruit weight (y) }\end{array}$ & 'Sidi Aissa' & $\mathrm{y}=1.87 \mathrm{x}+43.42$ & 0.92 & 84 \\
\hline Between water supply (x) & 'Orogrande' & $\mathrm{y}=2.75 \mathrm{x}+48.49$ & 0.98 & 97 \\
and fruit yield (y) & 'Orogrande' & $\mathrm{y}=1.76 \mathrm{x}+4.45$ & 0.92 & 84 \\
\hline
\end{tabular}

\subsection{Effect of Deficit Irrigation on Fruit Yield}

The RDI-1 strategy reduced yield for 'Sidi Aissa' but not for 'Orogrande' and RDI-2 had no effect on yield for both selections (Table 4). Yield was significantly decreased by PRD for both clementines, with an equal effect for PRD-3/4 and PRD-7 (Table 4). Across treatments, the reduction effect of PRD on yield was greater for 'Sidi Aissa', with 18-21\% compared to 'Orogrande', with a 16\% reduction. Linear regression analysis indicates that amount of water supply explained $84 \%$ and $99 \%$ of the variability observed in the yield respectively for both clementines (significant ' $r$ ' and $R^{2}$ values in Table 3), and that yield is highly significantly correlated with both fruit count per tree and individual fruit weight (significant ' $r$ ' and $\mathrm{R}^{2}$ values in Table 5). The RDI applied on clementine mandarin trees using water restrictions of $25-50 \%$ during fruit growth negatively affected fruit yield as a result of reduced fruit size. Compared to severe RDI with water supply of $35 \%$ of ETc, a moderate RDI with water supply of 50\% ETc from mid-July to mid-September, can successfully be applied to 'Clementina de Nules', allowing a $15 \%$ water saving without any detrimental effect on tree performance or economic return [72]. The PRD strategy applied to orange trees with $50 \%$ ETc resulted in a significant water saving, with no negative effect on fruit yield, and was concluded to be sustainable for orange orchards [44-46,75]. Variety and rootstock genotypes are reported to play a significant role in tree response to water deficit [36,37]. 
Table 4. Effect of irrigation strategies on total water applied during the crop cycle, yield and water use efficiency (WUE) for 'Sidi Aissa' and 'Orogrande' clementine trees.

\begin{tabular}{|c|c|c|c|c|c|}
\hline \multirow{2}{*}{$\begin{array}{l}\text { Irrigation } \\
\text { Strategy }\end{array}$} & \multirow{2}{*}{$\begin{array}{c}\text { Water Quantities } \\
\text { Applied }\left(\mathrm{m}^{3} \mathrm{Cycle}^{-1}\right)\end{array}$} & \multicolumn{2}{|c|}{ 'SidiAissa' } & \multicolumn{2}{|c|}{ ‘Orogrande' } \\
\hline & & Yield (Tons ha ${ }^{-1}$ ) & WUE $\left(\mathrm{kg} \mathrm{m}^{-3}\right)$ & Yield (Tons ha ${ }^{-1}$ ) & WUE $\left(\mathrm{kg} \mathrm{m}^{-3}\right)$ \\
\hline Cntl & 6675 & $15.45 \mathrm{a}$ & 2.31 & $19.68 \mathrm{a}$ & 2.94 \\
\hline RDI-1 & 5641 & $14.23 \mathrm{~b}$ & 2.52 & $17.94 \mathrm{a}$ & 3.18 \\
\hline PRD-3/4 & 4621 & 12. $23 \mathrm{c}$ & 2.74 & $16.37 \mathrm{~b}$ & 3.54 \\
\hline PRD-7 & 4621 & 12. $67 \mathrm{c}$ & 2.64 & $16.42 \mathrm{~b}$ & 3.55 \\
\hline RDI-2 & 6046 & $16.17 \mathrm{a}$ & 2.67 & $18.75 \mathrm{a}$ & 3.10 \\
\hline
\end{tabular}

Within columns, values followed by the same letters are not statistically different (Tukey's test at $5 \%$ level).

Table 5. Linear regression analysis between yield ( $\mathrm{y}$; tons $\mathrm{ha}^{-1}$ ) and individual-fruit weight ( $\mathrm{g}$ fruit ${ }^{-1}$ ) and fruit counts per tree for 'Sidi Aissa' and 'Orogrande' clementines.

\begin{tabular}{ccccc}
\hline Relationship & Cultivar & $\begin{array}{c}\text { Regression } \\
\text { Equation }\end{array}$ & $\begin{array}{c}\text { Correlation } \\
\text { Coefficient } \boldsymbol{r}\end{array}$ & $\begin{array}{c}\text { Coefficient of } \\
\text { Determination } \mathbf{R}^{\mathbf{2}} \mathbf{( \% )}\end{array}$ \\
\hline $\begin{array}{c}\text { Between yield (y) and } \\
\text { individual fruit weight }(\mathrm{x})\end{array}$ & 'Sidi Aissa' & $\mathrm{y}=0.878 \mathrm{x}-33.033$ & 0.94 & 88 \\
\hline $\begin{array}{c}\text { Between yield (y) and fruit } \\
\text { count per tree (x) }\end{array}$ & 'Sidi Aissa' & $\mathrm{y}=0.060 \mathrm{x}-4.841$ & 0.99 & 97 \\
\hline
\end{tabular}

\subsection{Effect of Deficit Irrigation Regimes on Water Supply, Water Saving and Water Use Efficiency}

During the experimental period (6 July-2 October) total cumulative reference evapotranspiration (ETo) and cumulative crop water requirements (ETc) were $421 \mathrm{~mm}$ and $241 \mathrm{~mm}$, respectively. As a result, total water supply during this period was $241 \mathrm{~mm}$ for Cntl, $180 \mathrm{~mm}$ for RDI-1 and $120 \mathrm{~mm}$ for PRD (PRD-3/4 and PRD-7). Trees of case RDI-2 received a total supply of $210 \mathrm{~mm}$. Consequently, water savings were $61 \mathrm{~mm}$ for RDI-1, $121 \mathrm{~mm}$ for PRD (both PRD-3/4 and PRD-7) and $31 \mathrm{~mm}$ for RDI-2, which represent $25 \%, 50 \%$ and $12.5 \%$ savings, respectively.

Taking into account the entire crop cycle from the beginning of November 2016 (flower induction) to the end of October 2017 (end of commercial fruit harvest), the total water supply was $6675 \mathrm{~m}^{3} \mathrm{ha}^{-1}$ for Cntl trees receiving 100\% ETc (Table 4). Therefore, water saving was $1034 \mathrm{~m}^{3} \mathrm{ha}^{-1}$ for RDI- 1 strategy, $2054 \mathrm{~m}^{3} \mathrm{ha}^{-1}$ for PRD (i.e., PRD-3/4 and PRD-7) and $629 \mathrm{~m}^{3} \mathrm{ha}^{-1}$ for RDI-2, thus representing 15\%, $31 \%$ and $9.5 \%$, respectively. As a result, WUE for the cultivar 'Sidi Aissa' under the DI strategies tested is in the range of 2.5 to $2.7 \mathrm{~kg} \mathrm{~m}^{-3}$ whereas it is $2.3 \mathrm{~kg} \mathrm{~m}^{-3}$ for Cntl trees (Table 4). For 'Orogrande', WUE values are 3.3 to $3.5 \mathrm{~kg} \mathrm{~m}^{-3}$ for the trees under DI compared to $2.9 \mathrm{~kg} \mathrm{~m}^{-3}$ for the Cntl trees (Table 4). The application of PRD to citrus trees allowed $40 \%$ of water saving with increased WUE [44,46]. The PRD was reported to reduce vegetative growth and plant water use more than fruit growth, maintain yield and increase WUE [76]. On the contrary, the application of RDI to 'Clementina de Nules' during the last part of fruit growth stage to fruit maturation resulted in 12 to $18 \%$ of water saving, and had no effect on fruit yield and fruit size [29]. A regression analysis was made between WUE and the total amounts applied to trees during the crop cycle, and it shows a decreasing linear and quadratic trend, with a more significant effect on 'Orogrande' than on 'Sidi Aissa' (Table 6). In addition, the linear regression indicates that $60 \%$ and $98 \%$ of the variability in WUE is due to the amount of water applied to 'Sidi Aissa' and 'Orogrande', respectively, which is a clear indication of a differential response of the cultivars/rootstock combinations used to irrigation water supply and that, for 'Sidi Aissa', other factors including the rootstock $[36,37]$, may be involved in the response of the trees to water supply.

Table 6. Regression analyses of the relationship between WUE $\left(y ; \mathrm{kg} \mathrm{m}^{-3}\right)$ and amount of water applied $\left(x ; 1000 \mathrm{~m}^{3}\right)$ to 'Orogrande' and 'Sidi Aissa' clementines.

\begin{tabular}{ccccc}
\hline \multirow{2}{*}{ Variety } & \multicolumn{2}{c}{ Quadratic Relationship } & \multicolumn{2}{c}{ Linear Relationship } \\
\cline { 2 - 5 } & Equation & $\mathbf{R}^{\mathbf{2}}$ & Equation & $\mathbf{R}^{\mathbf{2}}$ \\
\hline 'Orogrande' & $\mathrm{y}=0.05 \mathrm{x}^{2}-0.85 \mathrm{x}+6.42$ & 0.99 & $\mathrm{y}=-0.30 \mathrm{x}+4.92$ & 0.98 \\
'Sidi Aissa' & $\mathrm{y}=-0.11 \mathrm{x}^{2}+1.04 \mathrm{x}+0.14$ & 0.70 & $\mathrm{y}=-0.15 \mathrm{x}+3.38$ & 0.60 \\
\hline
\end{tabular}




\subsection{Effect of Deficit Irrigation Strategies on Fruit Juice Content and Quality}

Fruit of trees under RDI-1 and RDI-2 have juice content similar to that of fruit of Cntl trees in both cultivars, whereas the fruit of trees under PRD have significantly less juice (Table 7). The reduction as a result of PRD strategy was 11\% for 'Sidi Aissa' and 7\% for 'Orogrande'. In addition, regardless of the variety, juice of fruit from PRD trees had the highest TSS content, followed by that from RDI-1 and then that from RDI-2 trees. Juice of fruit from Cntl had the lowest TSS values for both cultivars (Table 8). In addition, juice of fruit of trees from DI treatments had lower acid content compared to juice of fruit of Cntl trees. As a result, the maturity index was greater for PRD fruit followed by RDI-1 fruit and then by RDI-2 fruit (Table 8), thus resulting in early fruit maturation compared to fruit of $\mathrm{Cntl}$ trees. These results confirm previous findings that the restriction of irrigation water during fruit enlargement can be used to induce early fruit maturation [29,30,35,46]. More importantly, RDI-1 had a limited negative effect on fruit size and yield (Table 3) and induced fruit maturity (Table 8). The RDI-2 had no effect on fruit juice content (Table 7), but the stress applied was sufficient to increase juice sugar content, reduce juice acidity and, thus, increase the maturity index, compared to fruits from Cntl trees (Table 8). Reports by others [29] indicated that, for 'Clementina de Nules', the application of RDI (with water restrictions of $25 \%$ and $50 \%$ of crop water requirements) during the end of summer-early fall, corresponding to the second half of the fruit growth stage and to fruit maturation, increased the fruit juice sugar and acid content. For orange trees subjected to PRD, there was no effect on yield but an increase in fruit juice content and in juice-sugar content was reported, and the extent of this increase was proportional to the stress level applied to the trees [46]. Other researchers [44] applied PRD to orange trees and obtained fruit with less juice but with higher sugar and acid contents indicating a potential effect of factors, such as rootstock, cultivar, environment of cultivation and level of stress applied to trees [33,37].

Table 7. Effect of irrigation strategies on juice content for 'Sidi Aissa' and 'Orogrande' clementine fruit at maturity (on 2 October 2017; in \%).

\begin{tabular}{ccc}
\hline \multirow{2}{*}{ Irrigation Strategy } & \multicolumn{2}{c}{ Variety } \\
\cline { 2 - 3 } & 'Sidi Aissa' & 'Orogrande' \\
\hline Cntl & $51.7 \mathrm{a}$ & $49.7 \mathrm{a}$ \\
RDI-1 & $48.8 \mathrm{ab}$ & $49.4 \mathrm{a}$ \\
PRD-3/4 & $46.3 \mathrm{~b}$ & $45.9 \mathrm{~b}$ \\
PRD-7 & $46.3 \mathrm{~b}$ & $46.8 \mathrm{~b}$ \\
RDI-2 & $49.3 \mathrm{ab}$ & $48.8 \mathrm{a}$ \\
\hline
\end{tabular}

Within columns, values followed by the same letter are not significantly different (Tukey's test at $5 \%$ level).

Table 8. Effect of irrigation strategies on juice total soluble solids (TSS, in \%), titratable acidity (TA, in \%) and fruit maturity index (TSS/TA) for 'Sidi Aissa' and 'Orogrande' clementine at fruit maturity

\begin{tabular}{ccccccc}
\hline \multirow{2}{*}{ Irrigation Strategy } & \multicolumn{3}{c}{ 'Sidi Aissa' } & \multicolumn{3}{c}{ 'Orogrande' } \\
\cline { 2 - 7 } & TSS & TA & TSS/TA & TSS & TA & TSS/TA \\
\hline Cntl & $10.48 \mathrm{c}$ & $1.36 \mathrm{a}$ & $7.68 \mathrm{c}$ & $11.36 \mathrm{~b}$ & $1.16 \mathrm{a}$ & $9.83 \mathrm{c}$ \\
RDI-1 & $10.76 \mathrm{ab}$ & $1.27 \mathrm{~b}$ & $8.50 \mathrm{ab}$ & $11.56 \mathrm{ab}$ & $1.12 \mathrm{bc}$ & $10.28 \mathrm{ab}$ \\
PRD-3/4 & $10.91 \mathrm{ab}$ & $1.23 \mathrm{~b}$ & $8.84 \mathrm{a}$ & $11.71 \mathrm{a}$ & $1.12 \mathrm{bc}$ & $10.37 \mathrm{a}$ \\
PRD-7 & $10.98 \mathrm{a}$ & $1.25 \mathrm{~b}$ & $8.80 \mathrm{ab}$ & $11.70 \mathrm{a}$ & $1.11 \mathrm{c}$ & $10.53 \mathrm{a}$ \\
RDI-2 & $10.69 \mathrm{bc}$ & $1.29 \mathrm{~b}$ & $8.29 \mathrm{~b}$ & $11.46 \mathrm{~b}$ & $1.14 \mathrm{ab}$ & $10.02 \mathrm{bc}$ \\
\hline
\end{tabular}

Within columns, values followed by the same letter are not significantly different (Tukey's test at $5 \%$ level).

\subsection{Effect of Irrigation Strategy on Soil Salinity}

The soil salinity data (expressed as 1:5 soil:water ratio extract) show values around $0.170 \mathrm{dS} \mathrm{m}^{-1}$ in the upper $10 \mathrm{~cm}$ of soil depth for all of the irrigation strategies (Figure 7). For Cntl and RDI-2 strategies, soil salinity increases slightly with soil depth to reach $0.230 \mathrm{dS} \mathrm{m}^{-1}$ in the $50-60 \mathrm{~cm}$ depth. For PRD 
strategies, salinity increased to reach a maximum of $0.240 \mathrm{dS} \mathrm{m}^{-1}$ for PRD-3/4 and $0.255 \mathrm{dS} \mathrm{m}^{-1}$ for PRD-7 in the 30-40 cm soil layer and dropped to the value recorded for the $0-10 \mathrm{~cm}$ in the $50-60 \mathrm{~cm}$ soil depth. For RDI-1 strategy, salinity increased, but at a slower rate, and reached a maximum of $0.260 \mathrm{dS} \mathrm{m}^{-1}$ in the 40-50 cm soil layer, then dropped to the value recorded for the $0-10 \mathrm{~cm}$ in the $50-60 \mathrm{~cm}$ soil layer. These salt levels are far below the threshold limit reported for citrus (i.e., $\mathrm{EC}=0.410 \mathrm{dS} \mathrm{m}^{-1}$ expressed as 1:5 soil:water ratio extract) [21]. However, the irrigation water is slightly saline $\left(\mathrm{EC}_{25^{\circ} \mathrm{C}}=1.18 \mathrm{dS} \mathrm{m}^{-1}\right)$ according to FAO report (http://www.fao.org/docrep/T0667E/t0667e05.htm). This water has salt content equivalent to that used in a six-year RDI experiment on clementines, for which they reported no salt accumulation in their soil (with EC at $25^{\circ} \mathrm{C}=0.8-1.1 \mathrm{dS} \mathrm{m}^{-1}$ for the saturated soil-paste extract) as a result of the heavy rains received in the experimental plot, which may have regularly leached the salts away from the root bulb [71]. In another long-term RDI study under arid climate, salt accumulation in the rootzone increased with the degree of water deficit, and this salt is regularly washed away in the case of full irrigation and also by the rains, to maintain an adequate rootzone environment, particularly in sandy soils [30]. Our results indicate that in the long run, there is a risk of salinity buildup in the 20-40 cm soil layer for the PRD strategies, coinciding with the deeper portion of the active roots particularly in the years with no rains or no sufficient water available for leaching the salts by irrigation. Taken together, these results indicate that salt buildup should be monitored when DI and PRD in particular is to be adopted as a routine irrigation strategy, particularly when salty waters are to be used.

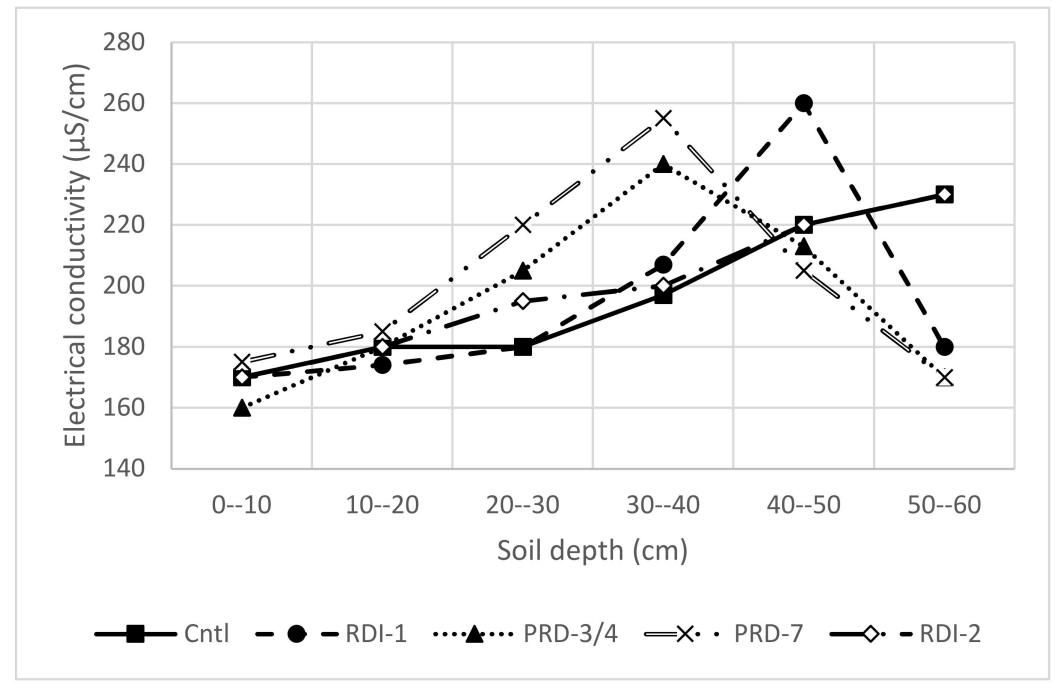

Figure 7. Pattern in soil electric conductivity according to soil depth and irrigation strategy.

\section{Conclusions}

Although the trial was performed for one crop cycle, it reports significant results with indicative indices as to the response of the tow clementine cultivars to different strategies of irrigation. The experimental period coincides with dry climatic conditions with little rain and with mild to very hot temperatures, low air relative humidity and high VPD giving rise to relatively high ETc. The two variety/rootstock combinations show significant different agricultural responses to water deficit and, consequently, variable results in yield and in quality and size of the fruit. Cntl, RDI-1 and PRD trees extract their water mainly from the upper 30-cm soil depth. Soil water depletion occurred more rapidly under high crop evapotranspiration days. During the no-irrigation period, PRD trees extract their water from the irrigated half of the root system as the soil water content of the non-irrigated half of the rootzone fell to the level of the permanent wilting point. Significant differences are observed between the two variety/rootstock combinations with 'Sidi Aissa' on 'Carrizo' citrange being more susceptible to water deficit stress compared to 'Orogrande' on Citrus volkameriana; this difference is more pronounced under PRD treatments with a significant reduction in fruit size and yield. Reduction in water supply 
during fruit maturation (RDI-2) has no negative effect on tree performance. Fruit maturity index increases under water restriction regimes as a result of reduced acid and increased sugar content in fruit juice. Salt accumulation is recorded for PRD in the root zone and for RDI-1 below the rootzone and this may be of concern if PRD strategy is used in a long run.

Taken together, these results indicate that under the experimental conditions, 'Sidi Aissa' on 'Carrizo' citrange should not be the choice in regions with limited water availability, and that PRD should not be recommended for clementine mandarins, since fruit size is an essential component in fruit quality, and that clementines naturally have the small-size fruit-market constraint. However, RDI applied during maturation can be recommended for clementines for water saving and for fruit maturity enhancement. Although limited in time, these results should be considered as indicators that will give the growers and the decision-makers or policy makers a good visibility of the impacts of irrigation strategies on the performance of specific varieties, taking into account the water scarcity in the region.

Author Contributions: Conceptualization, L.B. and R.C.-A.; Data curation, A.C. and C.A.; Formal analysis, A.C. and C.A.; Funding acquisition, R.C.-A.; Investigation, A.C. and C.A.; Methodology, M.E.-O., L.B. and R.C.-A.; Resources, R.C.-A.; Supervision, M.E.-O.; Writing-review \& editing, M.E.-O. All authors have read and agreed to the published version of the manuscript.

Funding: This research was in part funded, within the year 2016 Eranet MED framework (Contract $\left.n^{\circ}: 4\right)$, under the project "Water Saving in Agriculture (WASA): technological developments for the sustainable management of limited water resources in the Mediterranean area", by the Moroccan Ministry of Higher Education and Research.

Conflicts of Interest: Authors have no conflict of interest.

\section{References}

1. Schilling, J.; Freier, K.P.; Hertig, E.; Scheffran, J. Climate Change, Vulnerability and Adaptation in North. Africa with Focus on Morocco. Agric. Ecosyst. Environ. 2012, 156, 12-26. [CrossRef]

2. Hssaisoune, M.; Bouchaou, L.; Sifeddine, A.; Bouimetarhan, I.; Chehbouni, A. Moroccan groundwater resources and evolution with global climate changes. Geosciences 2020, 10, 81. [CrossRef]

3. Kadi, M.A.; Ziyad, A. Integrated Water Resources Management in Morocco. In Global Water Security; Springer: Singapore, 2018; pp. 143-163.

4. Marieme, S.E.; Abdelaziz, H.; Morjani, Z.E.A.E.; Redouane, C.-A.; Rashyd, Z.; Abdessadek, N.; Mouna, M.; Lhoussaine, B.; Elhassane, B. Assessment of global change impacts on groundwater resources in souss-massa basin. In Water Resources in Arid Areas: The Way Forward; Springer: Berlin/Heidelberg, Germany, 2017; pp. 115-140.

5. Bouchaou, L.; Tagma, T.; Boutaleb, S.; Hssaisoune, M.; El Morjani, Z.E.A. Climate change and its impacts on groundwater resources in Morocco: The case of the Souss-Massa Basin. In Climate Change Effects on Groundwater Resources. A Global Synthesis of Findings and Recommandations; Treidel, H., Martin-Bordes, J.L., Gurdak, J.J., Eds.; UNESCO, International Hydrological Programme: Paris, France, 2011; pp. 129-143.

6. N'da, A.B.; Bouchaou, L.; Reichert, B.; Hanich, L.; Ait Brahim, Y.; Chehbouni, A.; Beraaouz, E.H.; Michelot, J.L. Isotopic signatures for the assessment of snow water resources in the Moroccan High Atlas Mountains: Contribution to surface and groundwater recharge. Environ. Earth Sci. 2016, 75, 755. [CrossRef]

7. Hssaisoune, M.; Bouchaou, L.; N'da, B.; Malki, M.; Abahous, H.; Fryar, A.E. Isotopes to Assess Sustainability of Overexploited Groundwater in the Souss-Massa System (Morocco). Isot. Environ. Health Stud. 2017, 53, 298-312. [CrossRef] [PubMed]

8. Abahous, H.; Ronchail, J.; Sifeddine, A.; Kenny, L.; Bouchaou, L. Trend and change point analyses of annual precipitation in the Souss-Massa Region in Morocco during 1932-2010. Theor. Appl. Climatol. 2018, 134, 1153-1163. [CrossRef]

9. Bouchaou, L.; Michelot, J.L.; Vengosh, A.; Hsissou, Y.; Qurtobi, M.; Gaye, C.B.; Bullen, T.D.; Zuppi, G.M. Application of multiple isotopic and geochemical tracers for investigation of recharge, salinization, and residence time ofwater in the Souss-Massa aquifer, southwest of Morocco. J. Hydrol. 2008, 352, 267-287. [CrossRef] 
10. Tagma, T.; Hsissou, Y.; Bouchaou, L.; Bouragba, L.; Boutaleb, S. Groundwater nitrate pollution in Souss-Massa Basin (south-west Morocco). Afr. J. Environ. Sci. Technol. 2009, 3, 301-309.

11. Malki, M.; Bouchaou, L.; Hirich, A.; Ait Brahim, Y.; Choukr-Allah, R. Impact of agricultural practices on groundwater quality in intensive irrigated area of Chtouka-Massa, Morocco. Sci. Total Environ. 2017, 574, 760-770. [CrossRef]

12. Maroc Citrus. Statistiques. Available online: http://www.maroc-citrus.com/statistiques-2/ (accessed on 9 April 2020).

13. Elame, F.; Doukkali, R. Modélisation économique des ressources en eau dans le bassin du Souss-Massa. Rev. Marocaine Sci. Agron. Vét. 2018, 6, 124-131.

14. Word Bank. Moroccan Farmers save Water on Irrigation and Increase Agricultural Production. Available online: https:/www.worldbank.org/en/results/2019/10/16/moroccan-farmers-save-water-onirrigation-and-increase-agricultural-production (accessed on 16 October 2019).

15. Bouchaou, L.; Choukr-Allah, R.; Hirich, A.; Seif-Ennasr, M.; Malki, M.; Abahous, H.; Bouaakaz, B.; Nghira, A. Climate change and water valuation in Souss-Massa region: Management and adaptive measures. Eur. Water 2017, 60, 203-209.

16. Assouli, O.; El Bilali, H.; Abouabdillah, A.; Harbouze, R.; El Jaouhari, N.; Chaoui, M.; Bouabid, R. Transition from surface to drip irrigation in Morocco: Analysis through the multi-level perspective. Agrofor Int. J. 2018, 3, 142-151. [CrossRef]

17. Allen, R.G.; Pereira, L.S.; Raes, D.; Smith, M. Crop Evapotranspiration-Guidelines for Computing Crop Water Requirements-FAO Irrigation and Drainage; paper 56; Fao: Rome, Italy, 1998.

18. Tiercelin, J.-R. Traité D'irrigation; Technique et Documentation Lavoisier: Paris, France, 1998.

19. Snyder, R.L. Climate change impacts on water use in horticulture. Horticulturae 2017, 3, 27. [CrossRef]

20. Vahrmeijer, T.J.; Taylor, N.J. Citrus water use. In Citrus Health Benefits and Production Technology; Sajid, M., Amanullah, M., Eds.; IntechOpen Limited: London, UK, 2018; pp. 400-491. [CrossRef]

21. Agusti, M.F. Citricultura, 2nd ed.; Mundiprensa: Madrid, Spain, 2000.

22. Bain, J.M. Morphological, anatomical, and physiological changes in the developing fruit of the Valencia orange, Citrus sinensis (L) Osbeck. Aust. J. Bot. 1958, 6, 1-23. [CrossRef]

23. Davies, F.S.; Albrigo, L.G. Crop Production Science in Horticulture 2: Citrus; CAB International: Wallingford, UK, 1994.

24. Abobatta, W.F. Potential impacts of global climate change on citrus cultivation. MOJ Ecol. Environ. Sci. 2019, 4, 308-312.

25. Velez, J.E.; Intrigliolo, D.S.; Castel, J.R. Scheduling deficit irrigation of citrus trees with maximum daily trunk shrinkage. Agric. Water Manag. 2007, 90, 197-204. [CrossRef]

26. García-Tejero, I.; Romero-Vicente, R.; Jimenez-Bocanegra, J.A.; Martınez-Garcia, G.; Duran-Zuazo, V.H.; Muriel-Fernandez, J.L. Response of citrus trees to deficit irrigation during different phenological periods in relation to yield, fruit quality, and water productivity. Agric. Water Manag. 2010, 97, 689-699. [CrossRef]

27. Abrisqueta, I.; Ayars, J.E. Effect of alternative irrigation strategies on yield and quality of Fiesta raisin grapes grown in California. Water 2018, 10, 583. [CrossRef]

28. Behboudian, M.H.; Mills, T.M. Water management and water relations of horticultural crops using water stress to control vegetative growth and productivity of temperate fruit trees. Int. J. Hortic. Sci. Technol. 1997, 13, 59-63.

29. González-Altozano, P.; Castel, J.R. Regulated deficit irrigation in 'Clementina de Nules' citrus trees. I. Yield and fruit quality effects. J. Hortic. Sci. Biotechnol. 1999, 74, 706-713. [CrossRef]

30. Nagaz, K.; El Mokh, F.; Ben Hassen, N.; Masmoudi, M.M.; Ben Mechlia, N.; Baba Sy, M.O.; Belkheiri, O.; Ghiglieri, G. Impact of deficit irrigation on yield and fruit quality of orange Trees (Citrus sinensis, 1. Osbeck, cv. Meski maltaise) in southern Tunisia. Irrig. Drain. 2020, 69 (Suppl. 1), 186-193. [CrossRef]

31. Goldhamer, D.A. Regulated deficit irrigation in trees and vines. National Research Council. In Agricultural Water Management, Proceedings of a Workshop in Tunisia; The National Academies Press: Washington, DC, USA, 2007; pp. 71-80. [CrossRef]

32. Chalmers, D.J.; Mitchell, P.D.; van Heek, L. Control of peach tree growth and productivity by regulated water supply, tree density and summer pruning. J. Am. Soc. Hortic. Sci. 1981, 106, 307-312.

33. Sepaskhah, A.R.; Ahmadi, S.H. A review on partial root-zone drying irrigation. Int. J. Plant Prod. 2010, 4, 241-258. 
34. Ginestar, C.; Castel, J.R. Responses of young clementine citrus trees to water stress during different phenological periods. J. Hortic. Sci. 1996, 71, 551-559. [CrossRef]

35. Ballester, C.; Castel, J.; Introgliolo, D.S.; Castel, J.R. Response of Clementina de Nules citrus trees to summer deficit irrigation. Yield components and fruit composition. Agric. Water Manag. 2011, 98, 1027-1032. [CrossRef]

36. Garcia-Tejero, I.; Duran-Zuazo, V.H.; Jimenez-Bocanegra, J.A.; Muriel-Fernandez, J.L. Improved water use efficiency by deficit irrigation programmes: Implications for saving water in citrus orchards. Sci. Hortic. 2011, 128, 274-282. [CrossRef]

37. Garcia-Sanchez, J.G.; Perez, R.P.; Botia, P.; Martinez, V. Regulated deficit irrigation in Clemenules mandarin trees grafted on Cleopatra mandarin and Carrizo citrange. Proc. Int. Soc. Citric. 2004, 2, 566-570.

38. Saeed, H.; Grove, I.G.; Kettlewell, P.S.; Hall, N.W. Potential of partial root zone drying as an alternative irrigation technique for potatoes (Solanum tuberosum). Ann. Appl. Bot. 2008, 152, 71-80. [CrossRef]

39. Kang, S.; Liang, Z.; Pan, Y.; Shi, P.; Zhang, J. Alternate furrow irrigation for maize production in an arid area. Agric. Water Manag. 2000, 45, 267-274. [CrossRef]

40. Antolin, M.C.; Ayari, M.; Sanchez-Dias, M. Effects of partial rootzone drying on yield, ripening and berry ABA in potted Tempranillo grapevines with split roots. Austrian J. Grape Wine Res. 2006, 12, 13-20. [CrossRef]

41. Kirda, C.; Cetin, M.; Dasgan, Y.; Topcu, S.; Kaman, H.; Ekici, B.; Derici, M.R.; Ozguven, A.I. Yield response of greenhouse grown tomato to partial root drying and conventional deficit irrigation. Agric. Water Manag. 2004, 69, 191-201. [CrossRef]

42. Melgar, J.C.; Dunlop, J.M.; Syvertsen, J.P. Growth and physiological responses of the citrus rootstock Swingle citrumelo seedlings to partial rootzone drying and deficit irrigation. J. Agric. Sci. 2010, 148, 593-602. [CrossRef]

43. Romero-Conde, A.; Kusakabe, A.; Melgar, J.C. Physiological responses of citrus to partial rootzone drying irrigation. Sci. Hortic. 2014, 169, 234-238. [CrossRef]

44. Hutton, R.J.; Loveys, B.R. A partial root zone drying irrigation strategy for citrus-Effects on water use efficiency and fruit characteristics. Agric. Water Manag. 2011, 98, 1485-1496. [CrossRef]

45. Consoli, S.; Stagno, F.; Roccuzzo, G.; Cirelli, G.L.; Intrigliolo, F. Sustainable management of limited water resources in a young orange orchard. Agric. Water Manag. 2014, 132, 60-68. [CrossRef]

46. Consoli, S.; Stagno, F.; Vanella, D.; Boaga, J.; Cassiani, G.; Roccuzzo, G. Partial rootzone drying irrigation in orangeorchards: Effects on water use and crop production characteristics. Eur. J. Agron. 2017, 82, 190-202. [CrossRef]

47. Romero, P.; Dodd, I.C.; Martinez-Cutillas, A. Contrasting physiological effects of partial root zone drying in field-grown grapevine (Vitis vinifera L. cv. Monastrell) according to soil water availability. J. Exp. Bot. 2012, 63, 4071-4083. [CrossRef]

48. Maas, E.V. Salinity and citriculture. Tree Physiol. 1993, 12, 195-216. [CrossRef]

49. Sanchez, C.A.; Silvertooth, J.C. Managing saline and sodic soils for producing horticultural crops. HortTechnology 1996, 6, 99-107. [CrossRef]

50. Levy, Y.; Syvertsen, J. Irrigation water quality and salinity effects in citrus trees. Hortic. Rev. 2004, 30, 37-82.

51. Melgar, J.C.; Mohamed, Y.; Serrano, N.; Serrano, N.; Garcia-Galavis, P.A.; Navarro, C.; Parra, M.A.; Belloch, M.; Fernandez-Escobar, R. Long term responses of olive tree to salinity. Agric. Water Manag. 2009, 96, 1105-1113. [CrossRef]

52. Aragüésa, R.; Medinaa, E.T.; Zribia, W.; Claveríaa, I.; Álvaro-Fuentes, J.; Faci, J. Soil salinization as a threat to the sustainability of deficit irrigation under present and expected climate change scenarios. Irrig. Sci. 2014, 33, 67-79. [CrossRef]

53. Beniken, L.; Omari, F.E.; Dahan, R.; Van Damme, P.; Benkirane, R.; Benyahia, H. Evaluation de l'effet du stress hydrique et du porte-greffe sur la clémentine Citrus reticulata Swingle var. Sidi Aissa. J. Appl. Biosci. 2013, 71, 5692-5704. [CrossRef]

54. El-Otmani, M.; Bagayogo, S.; El-Fadl, A.; Benismail, M.C. Effect of regulated deficit irrigation on vegetative growth, fruiting, stomatal conductance and water use efficiency in 'Nules' Clementine under arid conditions of the Souss Valley of Morocco. Acta Hortic. 2015, 1065, 1757-1766. [CrossRef]

55. Barry, G.H.; Casle, W.S.; Davies, F.S. Rootstocks and plant water relations affect sugar accumulation of citrus fruit via osmotic adjustment. J. Am. Soc. Hortic. Sci. 2004, 129, 881-889. [CrossRef] 
56. El Guilli, M.; Belmehdi, I.; Zemzami, M. Citrus rootstocks in Morocco: Present situation and future prospects. Acta Hortic. 2015, 1065, 313-318. [CrossRef]

57. Citrus Academy. 4. Orchard establishment. In Citrus Planting Management Learner Guide, 1st ed.; Citrus Academy: Hillcrest, Republic of South Africa, 2017; p. 8.

58. El-Fadl, A.; El-Otmani, M.; Benismail, M.C.; Abouatallah, A.; El-Jaouhari, N. Optimizing irrigation water supply in a young citrus orchard. Proc. Int. Soc. Citric. 2010, 1, 795-804.

59. Zayani, A. Effet de L'irrigation à Déficit Régulé sur un Verger D'agrumes dans la Region du Souss. Travail de Fin d'Etudes Pour L'obtention du Diplôme D'ingenieur Agronome (MS Equivalent); Institut Agronomique et Vétérinaire Hassan II: Complexe Horticole d'Agadir, Ait Melloul, Morocco, 2010; p. 135.

60. Rhoades, J.D. Soluble salts. In Methods of Soil Analysis; Agronomy Monograph No 9; Part 2; Page, A.L., Ed.; American Society of Agronomy, Inc.: Madison, WI, USA, 1982; pp. 167-179.

61. Tukey, J. Comparing Individual Means in the Analysis of Variance. Biometrics 1949, 5, 99. [CrossRef]

62. Sato, K. Influence of drought and high temperature on citrus. In Abiotic Stress Biology in Horticultural Plants; Kanayama, Y., Kochetov, A., Eds.; Springer: Tokoyo, Japan, 2015; pp. 77-86. Available online: https://books. google.co.ma/books?id=zGkzBgAAQBAJ\&printsec=frontcover\&hl=fr\#v=onepage\&q\&f=false (accessed on 9 April 2020).

63. Hussain, A.; Aliwe, S. Production of Washington Navel Orange in a Desert Climate. Ph.D. Thesis, University of Arizona, Tucson, AZ, USA, 1984.

64. Kriedemann, P.E. Some photosynthetic characteristics of citrus leaves. Aust. J. Biol. Sci. 1968, 21, 895-905. [CrossRef]

65. DuToit, G. The Effect of Partial Root Zone Drying on the Partitioning of Dry Matter, Carbon, Nitrogen and Inorganic Ions in Grapevines. Ph.D. Thesis, University of Adelaide, Adelaide, Australia, 2005.

66. Kang, S.; Zhang, J. Controlled alternate partial root-zone irrigation: Its physiological consequences and impact on water use efficiency. J. Exp. Bot. 2004, 55, 2437-2446. [CrossRef]

67. Romero, P.; Pérez-Pérez, J.G.; del Amor, F.M.; Martinez-Cutillas, A.; Dodd, I.C.; Botia, P. Partial root zone drying exerts diffrent physiological responses on field-grown grapevine (Vitis vinifera cv. Monastrell) in comparison to regulated deficit irrigation. Funct. Plant Biol. 2014, 41, 1087-1106. [CrossRef]

68. Dry, P.R.; Loveys, B.R.; During, H. Partial drying of the root zone of grape. I. Transient changes in shoot growth and gas exchange. Vitis 2000, 39, 3-7.

69. Hsiao, T.C. Plant response to water stress. Ann. Rev. Plant Physiol. 1973, 24, 519-570. [CrossRef]

70. González-Altozano, P.; Castel, J.R. Regulated deficit irrigation in 'Clementina de Nules' citrus trees. II. Vegetative growth. J. Hortic. Sci. Biotechnol. 2000, 75, 388-392. [CrossRef]

71. Garcia-Tejero, I.F.; Duran-Zuazo, V.H.; Arriaga, J.; Muriel-Fernandez, J.L. Relationships between trunk- and fruit-diameter growths under deficit-irrigation programmes in orange trees. Sci. Hortic. 2012, 133, 64-71. [CrossRef]

72. Ballester, C.; Castel, J.; Castel, J.R.; Intrigliolo, D.S. Long-term response of 'Clementina de Nules' citrus trees to summer regulated deficit irrigation. Agric. Water Manag. 2014, 138, 78-84. [CrossRef]

73. Alahian, F. Effet de Différentes Stratégies de L'irrigation Déficitaire sur deux Variétés Précoces de Clémentinier dans le Souss. Travail de Fin d'Etude Présenté pour l'Obtention du Diplôme d'Ingénieur d'Etat en Agronomie, Option: Horticulture (MS Equivalent); Institut Agronomique et Vétérinaire Hassan II: Complexe Horticole d'Agadir, Ait Melloul, Morocco, 2018.

74. United Nations. UNECE Standard FFV-14 Concerning the Marketing and Commercial Quality Control of Citrus Fruits; United Nations: New York, NY, USA; Geneva, Switzerland, 2017.

75. Mossad, A.; Farina, V.; Lo Bianco, R. Fruit yield and quality of 'Valencia' orange trees under long-term partial rootzone drying. Agronomy 2020, 10, 164. [CrossRef]

76. Stoll, M.; Loveys, B.; Dry, P. Hormonal changes induced by partial rootzone drying of irrigated grapevine. J. Exp. Bot. 2000, 51, 1627-1634. [CrossRef]

(C) 2020 by the authors. Licensee MDPI, Basel, Switzerland. This article is an open access article distributed under the terms and conditions of the Creative Commons Attribution (CC BY) license (http://creativecommons.org/licenses/by/4.0/). 